\title{
Liquidity Ratios of Polish Commercial Banks ${ }^{\#}$
}

\author{
Pavla VODOVÁ*
}

\section{Introduction}

The financial crisis showed the importance of adequate liquidity risk measurement and management. Many banks struggled to maintain adequate liquidity during global financial crisis (BIS, 2009). The situation was not so dramatic in Polish banking sector. However, the deterioration in the macroeconomic situation weakened functioning of interbank market, increased the cost of money on the market and deepened the gap between deposits and loans (PFSA, 2009).

It is evident that bank liquidity and liquidity risk is very up-to-date and important topic which is of crucial importance of academicians and policymakers. There exist also a relatively large number of studies which use liquidity ratios. However, most of them use liquidity ratios only as an input for further analysis. Other studies focus more on the liquidity of the whole banking sector and so does not use the values of ratios of individual banks. As the aim of this paper is to evaluate comprehensively the liquidity positions of Polish commercial banks via five different liquidity ratios in the period of $2001-2011$ and to find out whether the strategy for liquidity risk management differs by the size of the bank, contribution of this paper is obvious.

The paper is structured as follows. After Introduction as a first section, next section characterizes bank liquidity and methods of its measuring. Third section describes data, next section deals with values of liquidity ratios. Last section captures concluding remarks.

\footnotetext{
\# The article is processed as an output of a research project Liquidity Risk of Commercial Banks in the Visegrad Countries registered by the Grant Agency under the registration number $\mathrm{P} 403 / 11 / \mathrm{P} 243$.

Ing. Pavla Vodová, Ph.D. - Assistant Professor; Department of Finance, School of Business Administration in Karviná, Silesian University in Opava, Univerzitní nám. 1934/3, 73340 Karviná, Czech Republic; <vodova@opf.slu.cz>.
} 


\section{Bank Liquidity and its Measuring}

According to Bank for International Settlements (BIS, 2008), liquidity is the ability of bank to fund increases in assets and meet obligations as they come due, without incurring unacceptable losses. Liquidity risk arises from the fundamental role of banks in the maturity transformation of short-term deposits into long-term loans.

The term liquidity risk includes funding liquidity risk and market liquidity risk. Funding liquidity risk is the risk that the bank will not be able to meet efficiently both expected and unexpected current and future cash flow and collateral needs without affecting either daily operations or the financial condition of the firm. Market liquidity risk is the risk that a bank cannot easily offset or eliminate a position at the market price because of inadequate market depth or market disruption (Drehman Nikolau, 2009). According to Crockett (2008), the dimension of market liquidity risk includes:

- market depth (the ability to execute large transactions without influencing prices unduly);

- tightness (the gap between bid and offer prices);

- intermediacy (the speed with which transaction can be executed);

- and resilience (the speed with which underlying prices are restored after disturbance).

Aspachs et al. (2005) define three mechanisms that banks can use to insure against liquidity crises:

- Banks hold buffer of liquid assets on the asset side of the balance sheet. A large enough buffer of assets such as cash, balances with central banks and other banks, debt securities issued by governments and similar securities or reverse repo trades reduce the probability that liquidity demands threaten the viability of the bank.

- Second strategy is connected with the liability side of the balance sheet. Banks can rely on the interbank market where they borrow from other banks in case of liquidity demand. However, this strategy is strongly linked with market liquidity risk.

- The last strategy concerns the liability side of the balance sheet, as well. The central bank typically acts as a Lender of Last Resort to provide emergency liquidity assistance to particular illiquid institutions and to provide aggregate liquidity in case of a systemwide shortage. 
Liquidity risk can be measured by two main methods: liquidity gap and liquidity ratios. Liquidity gap is the difference between assets and liabilities at both present and future dates. At any date, a positive gap between assets and liabilities is equivalent to a deficit (Bessis 2009).

Liquidity ratios are various balance sheet ratios which should identify main liquidity trends. These ratios reflect the fact that bank should be sure that appropriate, low-cost funding is available in a short time. This might involve holding a portfolio of assets than can be easily sold (cash reserves, minimum required reserves or government securities), holding significant volumes of stable liabilities (especially deposits from retail depositors) or maintaining credit lines with other financial institutions.

Various authors (such as Jiménez et al., 2010; Maechler et al., 2007; Ghosh, 2010; Tamirisa - Igan, 2008; Aspachs et al., 2005; Bunda Desquilbet, 2008; Moore, 2010; Rychtárik, 2009; Andries, 2009; Polouček, 2006 or Praet - Herzberg, 2008) provide various liquidity ratios. For the purpose of evaluation of the liquidity positions of Polish commercial banks we will use following five liquidity ratios (1)-(5):

$$
L 1=\frac{\text { liquid } \text { assets }}{\text { total assets }} \cdot 100(\%) \text {. }
$$

The liquidity ratio $L 1$ should give us information about the general liquidity shock absorption capacity of a bank. As a general rule, the higher the share of liquid assets in total assets, the higher the capacity to absorb liquidity shock, given that market liquidity is the same for all banks in the sample. Nevertheless, high value of this ratio may be also interpreted as inefficiency. Since liquid assets yield lower income liquidity bears high opportunity costs for the bank. Therefore it is necessary to optimize the relation between liquidity and profitability.

$$
L 2=\frac{\text { liquid assets }}{\text { deposits }+ \text { short term borrowing }} \cdot 100(\%) .
$$

The liquidity ratio $L 2$ uses concept of liquid assets as well. However, this ratio is more focused on the bank's sensitivity to selected types of funding (we included deposits of households, enterprises, banks and other financial institutions and funds from debt securities issued by the bank). The ratio $L 2$ should therefore capture the bank's vulnerability related to these funding sources. The higher is the value of the ratio, the higher is the capacity to absorb liquidity shock. 


$$
L 3=\frac{\text { liquid } \text { assets }}{\text { deposits }} \cdot 100(\%)
$$

The liquidity ratio $L 3$ is very similar to the liquidity ratio $L 2$. However, it includes only deposits to households and enterprises. In contrast to the ratio $L 2$, the ratio $L 3$ measures the liquidity of a bank assuming that the bank cannot borrow from other banks in case of liquidity need. This is relatively strict measure of liquidity but it enables us to capture at least the part of the market liquidity risk. The bank is able to meet its obligations in terms of funding (the volume of liquid assets is high enough to cover volatile funding) if the value of this ratio is $100 \%$ or more. Lower value indicates a bank's increased sensitivity related to deposit withdrawals.

$$
L 4=\frac{\text { loans }}{\text { total assets }} \cdot 100(\%) \text {. }
$$

The ratio $L 4$ measures the share of loans in total assets. It indicates what percentage of the assets of the bank is tied up in illiquid loans. Therefore the higher this ratio the less liquid the bank is.

$$
L 5=\frac{\text { loans }}{\text { deposits }} \cdot 100(\%) \text {. }
$$

The last liquidity ratio $L 5$ relates illiquid assets with liquid liabilities. Its interpretation is the same as in case of ratio L4: the higher this ratio the less liquid the bank is. Lower values of this ratio means that loans provide by the bank are financed by deposits.

These liquidity ratios are still in common. It is possible to calculate them only on the basis of publicly available data from banks' balance sheets and it is easy to interpret their values. Their disadvantage is the fact that they do not always capture all, or any of liquidity risk.

\section{Data}

We used unconsolidated balance sheet and profit and loss data over the period from 2001 to 2011 which were obtained from annual reports of Polish banks. The sample (Tab. 1) includes significant parts of Polish banking sectors. 
Tab. 1: Sample of banks

\begin{tabular}{|l|c|c|c|c|c|c|c|c|c|c|c|}
\hline Indicator & $\mathbf{0 1}$ & $\mathbf{0 2}$ & $\mathbf{0 3}$ & $\mathbf{0 4}$ & $\mathbf{0 5}$ & $\mathbf{0 6}$ & $\mathbf{0 7}$ & $\mathbf{0 8}$ & $\mathbf{0 9}$ & $\mathbf{1 0}$ & $\mathbf{1 1}$ \\
\hline Total No. of banks & 69 & 59 & 58 & 54 & 54 & 51 & 50 & 52 & 49 & 49 & 44 \\
\hline No. of observed banks & 24 & 27 & 31 & 34 & 34 & 31 & 30 & 30 & 28 & 25 & 19 \\
\hline $\begin{array}{l}\text { Share of obs. banks } \\
\text { on total assets (in \%) }\end{array}$ & 70 & 73 & 88 & 84 & 84 & 82 & 80 & 79 & 79 & 78 & 74 \\
\hline
\end{tabular}

Source: Author's processing

Nevertheless, the share of observed bank on total assets may appear to be quite low. Partly it is a consequence of growing role of branches of foreign banks; partly it is because we do not include data from building societies, mortgage banks and from specialized banks like Bank Gospodarstwa Krajowego which focus on very special financial products and services. The panel is unbalanced as some of the banks do not report over the whole period of time.

\section{Results}

We have calculated five different liquidity ratios (1) - (5) for each bank in the sample. In this section, we present descriptive statistics of liquidity ratios. Furthermore we focus on the relationship between bank liquidity and the size of the bank.

\section{Descriptive Statistics of Liquidity Ratios}

As higher value of the ratio $L 1$ means higher liquidity, it is evident that bank liquidity in Poland has decreased during analyzed period (Tab. 2). The decrease is really substantial and it is confirmed both by values of mean and median of the ratio.

The fall in liquidity of Polish banks is mainly a result of financial crisis (this impact is statistically significant - Vodová, 2012). Financial crisis and bank liquidity can influence each other in both directions: financial crisis can be caused by poor bank liquidity; or poor bank liquidity can be a result of financial crisis. Financial crisis affects banks in two different ways. First, the volatility of important macroeconomic variables influences unfavorably the business environment of banks. Second, the instability deteriorates the business environment of borrowers; it can worsen their ability to repay the loans which can lead to a decline in bank liquidity. 
Tab. 2: Descriptive statistics for liquidity ratio L1 (in \%)

\begin{tabular}{|c|c|c|c|c|c|c|c|c|c|c|c|}
\hline & 01 & 02 & 03 & 04 & 05 & 06 & 07 & 08 & 09 & 10 & 11 \\
\hline & & & & & & & & & 00 & & \\
\hline & 290 & & & & & & & & & & 7.7 \\
\hline & - & 15.0 & 0.6 & 1 & 21.3 & & & 16.4 & 4.4 & & 6.5 \\
\hline & 3 & 54.7 & .0 & 6 & 87.4 & 7 & 5 & 70.8 & 3 & 78 & 5.4 \\
\hline & 0 & 0.6 & 0.1 & 0.2 & 0.2 & 0.6 & & 3. & 3.0 & 0 & 0.9 \\
\hline
\end{tabular}

Source: Author's computation based on data from annual reports of banks

Liquidity of Polish banks fluctuated only slightly during the period 2001-2006. In 2007, the liquidity started to decline. Banks financed increased demand for loans both to households and non-financial companies also by reduction of the part of liquid assets. Mainly small and medium sized banks with poorly developed deposit base used funds from the interbank market (PFSA, 2008). In 2008, the increase in lending activity continued. However, some important structural weaknesses occurred: due to banks exceeded due from banks and Polish banking sector as a whole became net borrower in interbank market; household debts in foreign currency grew rapidly (up to more than $25 \%$ of total loan portfolio - PFSA, 2009); and very high loan-to-deposit ratio (see also Tab. 6) which signals that while financing loans, many banks have not enough clients deposits and are dependent on other source of financing such as loans from other banks or funds from debt securities issuance.

Average values can be sometimes tricky so it is useful to consider other items of descriptive statistics as well. We can see relatively extreme values of minimum and maximum. The lowest share of liquid assets in total assets had mainly AIG Bank Polska and Toyota Bank. These banks focused on lending activity till 2007 (see also Tab. 5). Bank Zachodni, BRE Bank and Kredyt Bank have lowest liquidity in period $2008-2010$. In all cases, the volume of liquid assets decreased as a result of reduction of interbank transaction in respective years. Although the decline in due from banks in other banks has not been so huge, the trend has been the same. This could be a signal of market liquidity risk. Maximum values were recorded by Deutsche Bank Polska, Bank BPS and in some years also by Rabobank Polska. These banks were strongly focused on trading on interbank market or with securities.

Tab. 3 contains values of the liquidity ratio $L 2$, which has been calculated as a share of liquid assets in deposits and short term borrowing. 
Although values of this ratio differ significantly from values of ratio $L 1$, the trend is the same. Results confirm decrease of liquidity in last six years.

Tab. 3: Descriptive statistics for liquidity ratio L2 (in \%)

\begin{tabular}{|l|r|r|r|r|r|r|r|c|c|c|r|}
\cline { 2 - 12 } \multicolumn{1}{c|}{} & \multicolumn{1}{c|}{$\mathbf{0 1}$} & $\mathbf{0 2}$ & $\mathbf{0 3}$ & $\mathbf{0 4}$ & $\mathbf{0 5}$ & $\mathbf{0 6}$ & \multicolumn{1}{c|}{$\mathbf{0 7}$} & $\mathbf{0 8}$ & $\mathbf{0 9}$ & $\mathbf{1 0}$ & \multicolumn{1}{c|}{11} \\
\hline Mean & 36.4 & 31.5 & 32.9 & 42.9 & 35.7 & 35.2 & 27.3 & 27.1 & 23.7 & 30.2 & 11.5 \\
\hline Median & 37.1 & 24.8 & 28.0 & 36.7 & 28.8 & 30.3 & 21.6 & 20.5 & 21.3 & 24.0 & 9.7 \\
\hline St. dev. & 19.3 & 20.6 & 21.7 & 33.7 & 29.8 & 25.5 & 20.4 & 22.2 & 16.9 & 22.8 & 7.7 \\
\hline Maxim. & 72.3 & 81.7 & 78.1 & 182. & 139. & 101. & 89.2 & 91.9 & 78.1 & 92.3 & 29.6 \\
\hline Minim. & 0.9 & 1.0 & 0.1 & 0.3 & 0.3 & 0.9 & 2.2 & 4.8 & 3.3 & 0.7 & 1.2 \\
\hline
\end{tabular}

Source: Author's computation based on data from annual reports of banks

High values of the ratio $L 2$ and thus high level of liquidity have occurred in Deutsche Bank Polska and Getin Noble Bank. AIG Bank Polska, Toyota Bank and Fiat Bank Polska had lowest value of the ratio L2.

As it was mentioned above, the liquidity ratio $L 3$ measures the liquidity of a bank assuming that the bank cannot borrow from other banks in case of liquidity need. Therefore it is a share of liquid assets in deposits of households and nonfinancial companies. Values of mean of the ratio are quite extreme because of a few banks. Gospodarczy Bank Wielkopolski, Mazowiecki Bank Regionalny, Rabobank Polska and Santander Consumer Bank had very low level of deposits (these banks use other source of financing, such as interbank deposits or issued debt securities) which caused extremely high values of the ratio. On the contrary, AIG Bank Polska and BOS Bank finance their activities mainly by deposits of households and non-financial companies which together with lower level of liquid assets resulted in very low values of ratio L3. When we focus on median we can see that the trend of liquidity is similar to previous two indicators (Tab. 4).

The volume of liquid assets of the bank is high enough to cover volatile funding if the value of this ratio is higher than $100 \%$. This was true only for a minority of banks: Gospodarczy Bank Wielkopolski, Mazowiecki Bank Regionalny, Rabobank Polska, Santander Consumer Bank, Bank BPS, Deutsche Bank Polska, HSBC Bank Polska, RCI Bank Polska, Toyota Bank Polska in 2003-2008, Bank DnB NORD in 20032004, Fiat Bank Polska in 2003-2004 and Getin Noble Bank in 20042006. Consequently, as it can be seen from values of medians, almost all Polish banks are sensitive to potential massive deposit withdrawals. 
Tab. 4: Descriptive statistics for liquidity ratio L3 (in \%)

\begin{tabular}{|l|r|r|r|r|r|r|}
\cline { 2 - 7 } \multicolumn{1}{c|}{} & \multicolumn{1}{c|}{$\mathbf{0 1}$} & \multicolumn{1}{c|}{$\mathbf{0 2}$} & \multicolumn{1}{c|}{$\mathbf{0 3}$} & \multicolumn{1}{c|}{$\mathbf{1 4}$} & \multicolumn{1}{c|}{$\mathbf{0 5}$} & \multicolumn{1}{c|}{$\mathbf{0 6}$} \\
\hline Mean & 107.5 & 89.9 & 189.4 & 135.4 & 406.3 & 312.1 \\
\hline Median & 46.6 & 39.8 & 48.6 & 54.9 & 49.2 & 51.6 \\
\hline St. dev. & 209.6 & 150.3 & 498.1 & 192.8 & 15.7 & 879.2 \\
\hline Maxim. & 902.3 & 668.8 & 2697.1 & 800.0 & 9850.0 & 3700.0 \\
\hline Minim. & 1.6 & 4.5 & 3.3 & 8.6 & 4.9 & 5.6 \\
\hline
\end{tabular}

\begin{tabular}{|l|r|r|r|r|c|}
\hline & \multicolumn{1}{c|}{$\mathbf{1 0 7}$} & \multicolumn{1}{c|}{$\mathbf{0 8}$} & \multicolumn{1}{c|}{$\mathbf{0 9}$} & \multicolumn{1}{c|}{$\mathbf{1 0}$} & \multicolumn{1}{c|}{11} \\
\hline Mean & 518.0 & 271.2 & 74.6 & 95.3 & 16.7 \\
\hline Median & 33.0 & 36.0 & 32.0 & 36.3 & 12.1 \\
\hline St. dev. & 27.1 & 932.9 & 124.9 & 227.1 & 15.7 \\
\hline Maxim. & 9647.0 & 5265.0 & 521.9 & 1146.9 & 58.8 \\
\hline Minim. & 13.2 & 5.9 & 6.4 & 1.7 & 1.2 \\
\hline
\end{tabular}

Source: Author's computation based on data from annual reports of banks

Descriptive statistics for liquidity ratio $L 4$ is presented in Tab. 5. Increase in lending activity confirms that Polish commercial banks have become less liquid. This is general trend. However, we can see that Polish banks were less willing to provide loans in 2008. PFSA (2009) stated that the decline in dynamics of loans was logical because growth of lending observed in 2006-2008 was impossible to be sustained. The peak phase of the economy occurred in 2007.

Tab. 5: Descriptive statistics for liquidity ratio L4 (in \%)

\begin{tabular}{|l|c|c|c|c|c|c|c|c|c|c|c|}
\cline { 2 - 11 } \multicolumn{1}{c|}{} & $\mathbf{0 1}$ & $\mathbf{0 2}$ & $\mathbf{0 3}$ & $\mathbf{0 4}$ & $\mathbf{0 5}$ & $\mathbf{0 6}$ & $\mathbf{0 7}$ & $\mathbf{0 8}$ & $\mathbf{0 9}$ & $\mathbf{1 0}$ & $\mathbf{1 1}$ \\
\hline Mean & 46.6 & 50.6 & 51.1 & 47.2 & 51.5 & 55.1 & 61.8 & 57.9 & 63.2 & 63.5 & 70.3 \\
\hline Median & 43.4 & 48.9 & 47.2 & 46.3 & 48.5 & 54.8 & 68.3 & 68.6 & 65.8 & 69.4 & 71.6 \\
\hline St. dev. & 16.0 & 19.5 & 23.5 & 22.9 & 22.0 & 23.8 & 22.6 & 23.4 & 18.9 & 18.6 & 10.8 \\
\hline Maxim. & 89.0 & 97.9 & 97.1 & 97.0 & 96.9 & 96.2 & 96.1 & 92.3 & 95.2 & 87.6 & 87.5 \\
\hline Minim. & 17.7 & 19.0 & 15.1 & 9.4 & 9.4 & 8.5 & 13.7 & 3.3 & 19.0 & 10.4 & 34.8 \\
\hline
\end{tabular}

Source: Author's computation based on data from annual reports of banks

Minimal and maximal values indicate significant differences in business strategies of banks. AIG Bank Polska, Toyota Bank, Fiat Bank Polska, Santander Consumer Bank, RCI Bank Polska or Mercedes-Benz Bank Polska have the highest share of loans in total assets and are most 
willing to provide loans. By contrast, Deutsche Bank Polska, Bank BPS, Bank Pocztowy and RBS Bank reached minimum values of the ratio LA. These banks focus more on trading on the interbank market and/or with securities. Minimum values were achieved also by banks that have their business either started or ended in particular years.

Results of the liquidity ratio $L 5$ can be found in Tab. 6. As in case of results from Tab. 5, high value of this ratio means low liquidity. The values of the last ratio also confirm that the liquidity of banks in both countries is gradually decreasing in recent years.

Tab. 6: Descriptive statistics for liquidity ratio L5 (in \%)

\begin{tabular}{|l|r|r|r|r|r|r|}
\cline { 2 - 7 } \multicolumn{1}{c|}{} & \multicolumn{1}{c|}{$\boldsymbol{1} 1$} & \multicolumn{1}{c|}{$\mathbf{0 2}$} & \multicolumn{1}{c|}{$\mathbf{0 3}$} & \multicolumn{1}{c|}{$\mathbf{0 4}$} & \multicolumn{1}{c|}{$\mathbf{0 5}$} & \multicolumn{1}{c|}{$\mathbf{0 6}$} \\
\hline Mean & 118.4 & 197.8 & 543.2 & 566.3 & 943.8 & 1005.9 \\
\hline Median & 82.1 & 84.3 & 84.4 & 85.8 & 78.5 & 90.3 \\
\hline St. dev. & 160.2 & 381.0 & 1654.9 & 1826.7 & 2730.1 & 2793.4 \\
\hline Maxim. & 823.9 & 1940.6 & 9050.0 & 8780.0 & 9990.0 & 9854.0 \\
\hline Minim. & 118.4 & 197.8 & 543.2 & 566.3 & 943.8 & 1005.9 \\
\hline
\end{tabular}

\begin{tabular}{|l|r|r|r|c|r|}
\hline & \multicolumn{1}{|c|}{$\mathbf{0 7}$} & \multicolumn{1}{c|}{$\mathbf{0 8}$} & \multicolumn{1}{c|}{$\mathbf{0 9}$} & \multicolumn{1}{c|}{$\mathbf{1 0}$} & \multicolumn{1}{c|}{$\mathbf{1 1}$} \\
\hline Mean & 1039.9 & 758.4 & 459.1 & 134.3 & 102.3 \\
\hline Median & 103.9 & 107.6 & 102.6 & 100.4 & 102.3 \\
\hline St. dev. & 2778.8 & 2371.9 & 1774.3 & 138.6 & 46.2 \\
\hline Maxim. & 9701.1 & 9985.0 & 9985.0 & 769.9 & 223.8 \\
\hline Minim. & 22.8 & 10.3 & 31.2 & 13.5 & 61.1 \\
\hline
\end{tabular}

Source: Author's computation based on data from annual reports of banks.

Liquidity ratio $L 5$, or in other words loan-to-deposit ratio indicates to which extent loans provide by the bank are financed by its deposits. High values of the mean and median means that only some banks (Alior Bank, Bank BPS, Bank BHZ, Bank Handlowy, Bank of Tokyo - Mitsubishi UFJ, Bank Pocztowy, Bank Pekao, Bank Zachodni, Deutsche Bank Polska or ING Bank Slaski) finance their lending activity by own clients deposits. Most Polish banks constantly need other source of financing such as loans from other banks or funds from debt securities issuance. Large proportion of funds is given by parent institutions (PFSA, 2009).

To reduction of the average value of the ratio, mainly Bank BPS, Bank Pocztowy and Deutsche Bank Polska significantly contributed. On the contrary, extremely high maximum value (and thus extremely high 
dependence on other sources of funding) reached Fiat Bank Polska, Gospodarczy Bank Wielkopolski, Rabobank Polska and Toyota Bank Polska. Porsche Bank, Gospodarczy Bank Wielkopolski and Rabobank Polska strongly rely on interbank market, other banks on debt securities issuance.

\section{Liquidity Ratios by Group of Banks}

Now we focus on the relationship between the size of the bank and its liquidity. We will take into account only the values of ratios $L 1$ and $L 4$, because these ratios are easy to interpret and did not achieve so extreme values.

We will differ among small, medium-sized and large banks based on the amount of their total assets. We will differ among small, medium-sized and large banks based on the amount of their total assets. We define large banks as banks with total assets greater than $6 \%$ of the total assets of the banking sector. Medium-sized banks have total assets of between $2 \%$ and $6 \%$ of these assets. Banks with total assets of less than $2 \%$ of the total assets of the banking sector are considered as small. Our sample included 4-5 large banks, 4-6 medium-sized banks and 6-24 small banks in particular years.

Fig. 1: Liquidity ratio L1 by group of Polish banks

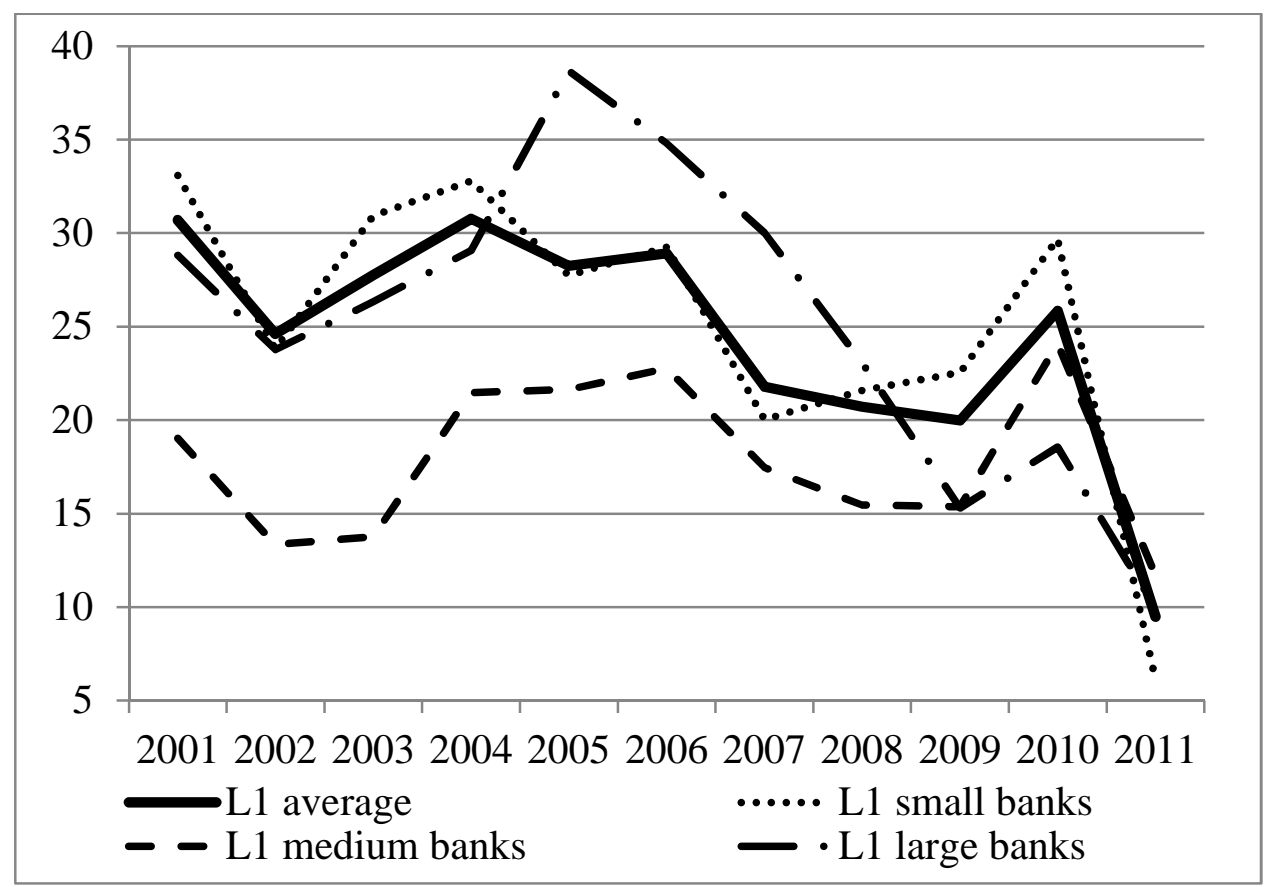

Source: Author's computation based on data from annual reports of banks. 
As it can be seen from Figure 1, small banks are most liquid and holds buffer of liquid assets. Liquidity of medium-sized banks is the lowest. However, also the level of liquid assets of large banks is almost for the whole period below average (with the exception of the period 20042007). So we can conclude that medium-sized and large Polish banks strongly rely on the interbank market or on a liquidity assistance of Lender of Last Resort.

Fig. 2: Liquidity ratio L4 by group of Polish banks

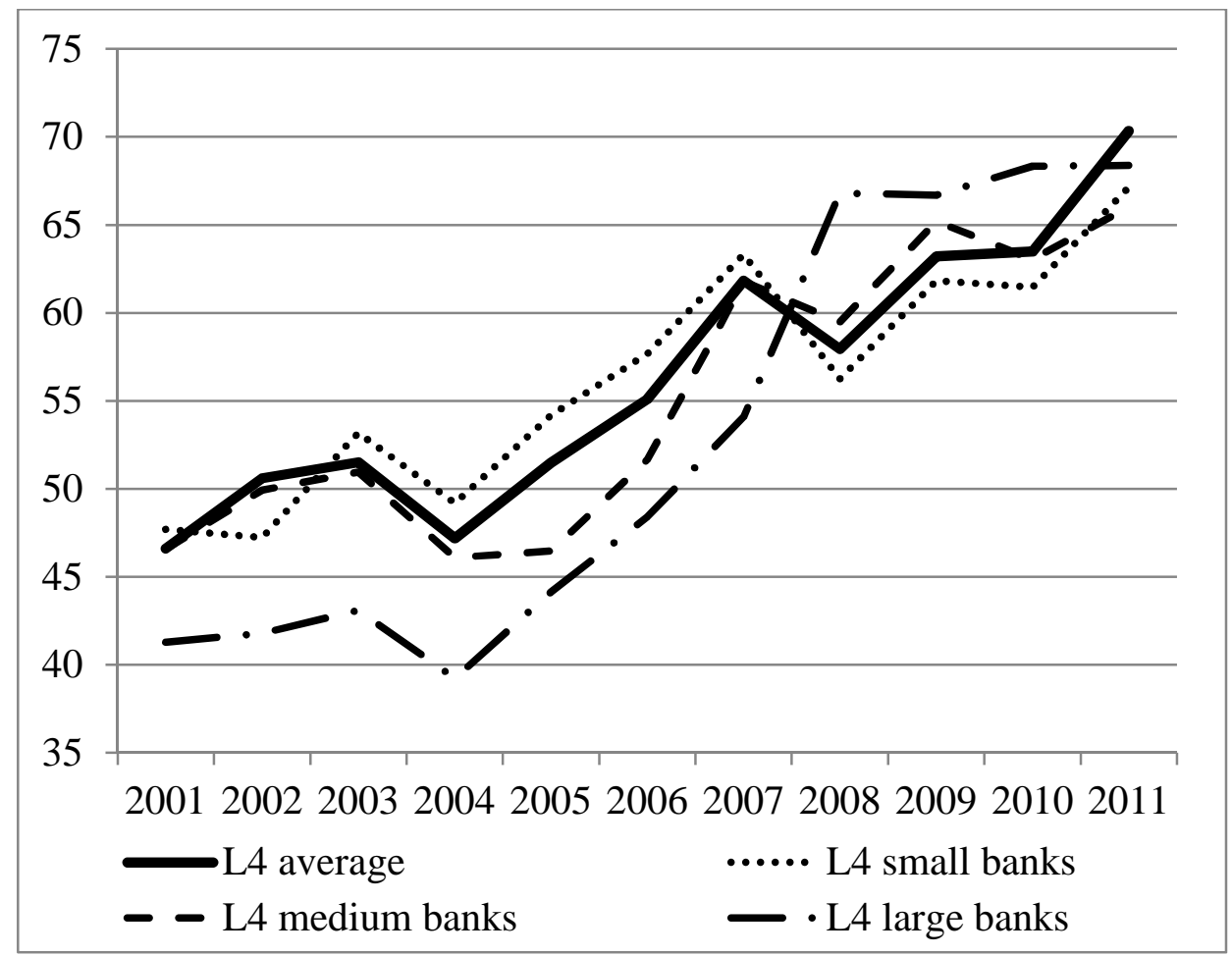

Source: Author's computation based on data from annual reports of banks.

The results of liquidity ratio $L 4$ by group of banks are quite surprising: almost for the whole analyzed period, small and medium sized banks are most willing to lend and thus theoretically the least liquid (Fig. 2). This is true for medium-sized banks which are the least liquid but for small banks this is the completely opposite finding. To interpret the values of both ratios together, we should conclude that small banks are the most liquid and most willing to provide loans; medium-sized banks are the least liquid because of their lending activity. The situation is different in period 2008-2011: large banks are most willing to lend which is accompanied by substantial decrease of their liquidity. 


\section{Conclusion}

The aim of this paper was to evaluate comprehensively the liquidity positions of Polish commercial banks via different liquidity ratios in the period of $2001-2011$ and to find out whether the strategy for liquidity risk management differs by the size of the bank.

We have calculated five different liquidity ratios for each bank in the sample. Values of ratios are influenced by business strategy of banks.

According to values of ratios using liquid assets, bank liquidity has decreased during analyzed period, mainly as a result of financial crisis which affected the Polish banking sector already in 2007. Polish banking sector suffered from some structural weaknesses: very high loan-todeposit ratio, long net foreign currency position and loans provided to foreign customers. Almost all Polish banks are sensitive to potential massive deposit withdrawals.

Results of ratios based on the share of loans showed that banks have become less liquid also due to the increase in their lending activity. Probably as a result of the financial crisis, Polish banks were less willing to provide loans in 2008. Only some banks finance their lending activity by own clients deposits. Most banks constantly need other source of financing such as loans from other banks or funds from debt securities issuance which increases their vulnerability.

Furthermore we focused on the relationship between the size of the bank and its liquidity. We have found that while ensuring liquidity, large and medium sized banks rely on the interbank market or on a liquidity assistance of the Lender of Last Resort and small banks hold buffer of liquid assets.

\section{References:}

[1] Andries, A. M. (2009): A Comparative Analysis of Performance and Soundness Indicators of the Main Romanian Banks. Scientific Annals of the "Alexandru Ioan Cuza" University of Iasi: Economic Science Series, 2009, vol. 56, pp. 45-70.

[2] Aspachs, O. - Nier, E. - Tiesset, M. (2005): Liquidity, Banking Regulation and the Macroeconomy. Evidence on Bank Liquidity Holdings from a Panel of UK-Resident Banks. [on-line], Basel, Bank for International Settlements, c2005, [cited $4^{\text {th }}$ February, 2013], $\langle$ http://www.bis.org/bcbs/events/rtf05AspachsNierTiesset.pdf $>$. 
Vodová, P.: Liquidity Ratios of Polish Commercial Banks.

[3] BIS (2008): Principles for Sound Liquidity Risk Management and Supervision. [on-line], Basel, Bank for International Settlements, c2008, [cited $4^{\text {th }}$ February, 2013],

<http://www.bis.org/publ/bcbs144.pdf>.

[4] BIS (2009): International Framework for Liquidity Risk Measurement, Standards and Monitoring. Basel, Bank for International Settlements, c2009, [cited $4^{\text {th }}$ February, 2013],

<http://www.bis.org/publ/bcbs188.pdf>.

[5] Bessis, J. (2009): Risk Management in Banking. Chichester, Wiley, 2009.

[6] Bunda, I. - Desquilbet, J.B. (2008): The Bank Liquidity Smile across Exchange Rate Regimes. International Economic Journal, 2008, vol. 22, no. 3, pp. 361-386.

[7] Crockett, A. (2008): Market Liquidity and Financial Stability. [on-line], Paris, Banque de France Financial Stability Review no. 11, pp.13-17, c2008, [cited $4^{\text {th }}$ February, 2013],

<http://www.banque-france.fr/fileadmin/user_upload/banque_de_fra nce/publications/Revue_de_la_stabilite_financiere/etud3_0208.pdf $>$.

[8] Drehman, M. - Nikolau, K. (2009): Funding Liquidity Risk. Definition and Measurement. [on-line], Frankfurt am Main, European Central bank Working Paper Series no. 1024, c2009, [cited $4^{\text {th }}$ February, 2013], <http://www.ecb.europa.eu/pub/pdf/scpwps/ecbwp1024.pdf> .

[9] Ghosh, S. (2010): Credit Growth, Bank Soundness and Financial Fragility: Evidence from Indian Banking Sector. South Asia Economic Journal, 2010, vol. 11, no. 1, pp. 69-98.

[10] Jiménez, G. - Ongena, S. - Peydró, J. - Saurina, J. (2010): Credit Supply: Identifying Balance-Sheet Channel with Loan Applications and Granted Loans. [on-line], Frankfurt am Main, European Central bank Working Paper Series no. 1179, c2010, [cited $4^{\text {th }}$ February, 2013], <http://www.ecb.europa.eu/pub/pdf/scpwps/ecbwp1179.pdf>.

[11] Maechler, A.M. - Mitra, S. - Worrell, D. (2007): Decomposing Financial Risks and Vulnerabilities in Eastern Europe. [on-line], Washington, D. C. Working Paper 07/248, c2007, [cited $4^{\text {th }}$ February, 2013], <https://www.imf.org/external/pubs/ft/wp/2007/wp07248.pdf>. 
[12] Moore, W. (2010): How Do Financial Crises Affect Commercial Bank Liquidity? Evidence from Latin America and the Caribbean. [on-line], Munich, Munich Personal RePEC Archive Paper no. 21473, c2010, [cited $4^{\text {th }}$ February, 2013], $<$ http://mpra.ub.uni-muenchen.de/21473/1/Determinants_of_Liquidit y_in_Latin_America.pdf >.

[13] PFSA (2008): Report on the Condition of Polish Banks in 2007. Warsaw, Polish Financial Supervision Authority, 2008.

[14] PFSA (2009). Report on the Condition of Polish Banks in 2008. Warsaw, Polish Financial Supervision Authority, 2009.

[15] Polouček, S. (2006): Bankovnictví. Praha, C. H. Beck, 2006.

[16] Praet, P. - Herzberg, V. (2008): Market Liquidity and Banking Liquidity: Linkages, Vulnerabilities and the Role of Disclosure. [on-line], Paris, Banque de France Financial Stability Review no. 11, pp. 95-109, c2008, [cited $4^{\text {th }}$ February, 2013],

$<$ http://www.banque-france.fr/fileadmin/user_upload/banque_de_fra nce/publications/Revue_de_la_stabilite_financiere/etud11_0208.pdf>.

[17] Rychtárik, Š. (2009): Liquidity Scenario Analysis in the Luxembourg Banking Sector. [on-line], Luxembourg, Banque Centrale du Luxembourg Working Paper no. 41, c2009, [cited $4^{\text {th }}$ February, 2013], <http://www.bcl.lu/fr/publications/cahiers_etudes/41/BCLWP041.pdf>.

[18] Tamirisa, N. T. - Igan, D. O. (2008): Are Weak Banks Leading Credit Booms? Evidence from Emerging Europe. Comparative Economic Studies, 2008, vol. 50, no. 4, pp. 599-619.

[19] Vodová, P. (2012): Determinants of commercial banks' liquidity in Poland. In Ramík, J. - Stavárek, D. (ed.): Proceedings of the 30th International Conference Mathematical Methods in Economics 2012. Karviná, Silesian University in Opava, 2012, pp. 962-967. 


\title{
Liquidity Ratios of Polish Commercial Banks
}

\author{
Pavla VODOVÁ
}

\begin{abstract}
As liquidity problems of some banks during global financial crisis reemphasized, liquidity is very important for functioning of financial markets and the banking sector. The aim of this paper is therefore to evaluate comprehensively the liquidity positions of Polish commercial banks via five different liquidity ratios in the period of 2001- 2011 and to find out whether the strategy for liquidity management differs by the size of the bank. The results enable us to conclude that liquidity of Polish banks has decreased in recent years, partly as a result of higher lending activity but mainly due to the financial crisis. Almost all Polish banks are sensitive to potential massive deposit withdrawals. Only some banks finance their lending activity by deposits; most banks are dependent on other sources of finance. Large and medium sized banks rely on the interbank market or on a liquidity assistance of the Lender of Last Resort, small banks hold buffer of liquid assets.
\end{abstract}

Key words: Liquidity ratio; Liquidity risk; Commercial banks.

JEL classification: G21, G01. 